\title{
First report of Sugarcane mosaic virus in achira (Canna edulis Ker.) in Nariño, Colombia
}

\section{Primer registro del Sugarcane mosaic virus en achira (Canna edulis Ker.) en Nariño, Colombia}

\author{
Carlos Betancourth ${ }^{1}$; Carlos Salomón ${ }^{2}$; Santiago Montaño ${ }^{3}$; Claudia Salazar ${ }^{4}$; Pedro Uribe ${ }^{5}$; \\ Angélica Martínez ${ }^{6}$; Lucely Muñoz ${ }^{7}$ Maritza Cuervo ${ }^{8}$
}

1Ing. Agrónomo, Ph.D. Universidad de Nariño, Pasto - Nariño, Colombia; e-mail: cbet70@yahoo.com; (Dhttps://orcid.org/0000-0001-6573-4230

${ }^{2}$ Ing. Agrónomo. Universidad de Nariño, Pasto - Nariño, Colombia; e-mail: cassolarte@gmail.com; Dhttps://orcid.org/0000-0003-4213-3461

${ }^{3}$ Ing. Agrónomo. Universidad de Nariño, Pasto - Nariño, Colombia; e-mail: santiago10320091@gmail.com; (Dhttps://orcid.org/0000-0003-3216-5654

${ }^{4}$ Ing. Agrónomo, Ph.D. Universidad de Nariño, Pasto - Nariño, Colombia; e-mail: claudiasalazarg@yahoo.com; Dhttps://orcid.org/0000-0002-5461-2761

${ }^{5}$ Ing. Agrónomo, Ph.D. Corporación colombiana de investigación agropecuaria - Agrosavia, C.I. Obonuco, Obonuco - Nariño, Colombia; e-mail: puribe@ agrosavia.co; Dhttps://orcid.org/0000-0002-1568-9512

${ }^{6}$ Bacterióloga M.Sc. Centro Internacional de Agricultura Tropical - CIAT, Palmira - Valle del Cauca, Colombia; e-mail: a.m.martinez@cgiar.org; Dhttps://orcid. org/0000-0002-6121-6361

${ }^{7}$ Tecnóloga Industrial. Centro Internacional de Agricultura Tropical - CIAT, Palmira - Valle del Cauca, Colombia; e-mail: I.m.mallarino@cgiar.org; Dhttps:// orcid.org/0000-0002-4594-5476

${ }^{8}$ Ing. Agrónomo, M.Sc. Centro Internacional de Agricultura Tropical - CIAT, Palmira - Valle del Cauca, Colombia; e-mail: m.cuervo@cgiar.org; Dhttps://orcid. org/0000-0002-4418-699X

How to cite: Betancourth, C.; Salomón, C.; Montaño, S.; Salazar, C.; Uribe, P.; Martínez, A.; Muñoz, L.; Cuervo, M. 2020. First report of Sugarcane mosaic virus in achira (Canna edulis Ker.) in Nariño, Colombia. Rev. U.D.C.A Act. \& Div. Cient. 23(1):e1461. http://doi. org/10.31910/rudca.v23.n1.2020.1461

Open access article published by Revista U.D.C.A Actualidad \& Divulgación Científi ca, under Creative Commons License CC BY-NC 4.0

Received: July 17, 2019

Accepted: January 27, 2020

Edited by: Ingeborg Zenner de Polanía

\begin{abstract}
Achira (Canna edulis Ker.) is a cultivated species for handcrafted food products and starch production. In Colombia is estimated an achira cultivated area of 800 ha; in the department of Nariño there has been a disturbance of viral etiology, known by farmers as Streak Virus, due to its symptoms in the leaves, but without previous records in the area. The disease causes losses in performance, although they have not been established precisely. In order to clarify the nature of this pathology and the identity of the pathogen associated with
\end{abstract}

the problem, an investigation was carried out at the University of Nariño, by means of molecular tests of PCR and RT-PCR, sequencing, serology and electron microscopy, of foliar samples collected in the producing areas. The most outstanding symptoms in affected tissues were yellow mosaic, mottled, chlorotic streak and ribs discoloration, among others. There were no cytoplasmic inclusions similar to those produced by Potyvirus, nor viral particles were observed, nor serology positive results, but it was possible to achieve the amplification of a cDNA fragment, with specific primers for Potyvirus and 98\% of homology of the sequences with 
Sugarcane mosaic virus. This is the first SCMV report in achira in Nariño, Colombia.

Keywords: molecular detection; virus; symptoms; achira.

\section{RESUMEN}

La achira (Canna edulis Ker.) es una especie utilizada para la producción de almidón y alimentos artesanales. En Colombia, se estima un área cultivada de 800ha; en el departamento de Nariño, se viene presentando un disturbio de etiología viral, conocido por los agricultores como el rayado, por sus síntomas en las hojas, pero sin registros previos en esta zona. La enfermedad causa pérdidas en el rendimiento, aunque no se ha establecido con precisión. Con el objetivo de esclarecer la naturaleza de dicha patología y la identidad del patógeno asociado al problema, en la Universidad de Nariño, se realizó una investigación, mediante pruebas moleculares de PCR y RT-PCR, secuenciación, serología y microscopía electrónica, de muestras foliares colectadas en las zonas productoras. Los síntomas más sobresalientes en tejidos afectados fueron mosaico amarillo, moteado, rayado clorótico, aclaramiento de nervaduras entre otros. No se detectaron inclusiones citoplasmáticas similares a las producidas por Potyvirus, ni se observaron partículas virales, tampoco hubo resultados positivos con serología, pero sí se logró amplificación de un fragmento de cDNA, con cebadores específicos para Potyvirus y homología de $98 \%$ de las secuencias con el virus Sugarcane mosaic virus SCMV. Este es el primer reporte de SCMV en achira en Nariño, Colombia.

Palabras clave: detección molecular; virus; síntomas; achira.

\section{INTRODUCTION}

Achira (Canna edulis Ker.) belongs to the Cannaceae (Tanaka, 2004) family; it is of South American origin and is grown in Latin America, Caribbean, Australia and Asia (Corpoica, 2001; Rodríguez et al. 2003), mainly to extract starch from its rhizomes, which is used in food preparation such as bread, cakes and pasta. In Colombia, these activities are important for rural economy of several departments and farmers generally use local planting materials (Caicedo et al. 2003; Torres, 2004; Corpoica, 2001).

In Taiwan, Vietnam and southern China, the species is sown between 2,000 and 3,000m. a.s.l. (Kasemwong et al. 2003; Roca and Manrique, 2005) and in Colombia, the species is grown in areas with altitudes below 2,700m (Ariza León et al. 2013), it is estimated that the achira starch demand per year in the country is 1,681.65t. The main producers are the departments of Nariño with 502ha, Huila 81ha and Cauca 24ha (Agronet, 2016). The plantations are established with genotypes local of regional origin, selected by farmers (Caicedo et al. 2003).

Among the limiting factors for crop production are phytosanitary problems, and particularly diseases associated with viruses, since they significantly reduce yields reaching losses of $70 \%$ or more, and are hard to manage (Hull, 2014).
Worldwide, several species of viruses affecting achira have been reported for years, Bean yellow mosaic virus, Potyvirus (BYMV) (Castillo et al. 1956), Tomato aspermy virus, Cucumovirus (TAV) (Hollings et al. 1971), Cucumber mosaic virus, Cucumovirus (CMV) (Lockhart, 1988), Canna yellow mottle virus, Badnavirus (CYMV) (Yamashita et al. 1985), Canna yellow streak virus, Potyvirus (CaYSV) (Monger et al. 2007), Tomato spotted wilt virus, Tospovirus (TSWV) (Moini et al. 2000) and Sugarcane mosaic virus, Potyvirus (SCMV) (Tang et al. 2016).

In Colombia, infections caused by CMV have been registered in the Canna edulis species (Castaño et al. 1994; Castaño et al. 1995; Reichel et al. 1995) and Banana streak virus, Badnavirus (BSV) (Reichel et al. 1996). Mixed infections of filamentous particles similar in their morphology to species of the genus Potexvirus (Reichel, 2007) and bacilliform particles similar to species of the genus Badnavirus have also been observed in achira plants with viral symptoms, from the department of Nariño (Reichel, data sin publish).

In the department of Nariño, achira is grown in the municipalities of La Cruz, San Pablo, El Tablón, Colón, Belén and Albán (Consolidado Agropecuario - Nariño, 2015). At present, there is no detailed knowledge of the virus species present in the crops, nor have been applied the diagnostic methods based on serological or molecular techniques that are available worldwide for these pathogens. In addition, their means of transmission and other biological characteristics of epidemiological interest are not known.

This situation motivated the development of the current research between the University of Nariño, Agrosavia and CIAT, aiming to establish solutions in the diagnosis and detection of viruses, through the standardization of serological and molecular protocols that serve as a starting point for such diseases management.

\section{MATERIALS AND METHODS}

Localization. This research was carried out at the University of Nariño (Pasto - Nariño) and at the CIAT International Center for Tropical Agriculture (Palmira - Valle del Cauca), under laboratory conditions.

Plant material. Plant samples were taken in La Cruz municipality, which is the main achira production area in Nariño and in an Achira germoplasm collection of AGROSAVIA (Obonuco-Pasto), with genotypes from the departments of Cundinamarca, Nariño and Huila.

Samples were taken from symptomatic and asymptomatic plants, based on symptoms reported for pathologies associated with viruses in achira (Castaño et al. 1994; Castaño et al. 1995; Reichel et al. 1995; Rajakaruna et al. 2014; Verchot \& Rajakaruna, 2013). The sampling included the recollection of foliar tissues, which were labeled, wrapped in paper towels and placed in plastic bags for transport to the laboratories. The plant material was kept in a refrigerator at $4^{\circ} \mathrm{C}$ until processing. 
Evaluation and visual description of viral symptoms. The monitoring and visual description of 10 achira plants was carried out for six weeks, with photographic record. The symptoms evolution was evaluated in each plant, from the first leaf outbreak, following recommendations of other authors (Armitage et al. 1990; Hunger \& Sherwood, 1985; Lockhart, 1988; Monger et al. 2007; Pappu \& Druffel, 2008; Zhang et al. 2011).

\section{Virus detection by molecular tests}

DNA extraction. Leaf samples from symptomatic achira plants were used, following the method of Prince et al. (1993), taking $0.4 \mathrm{~g}$ of tissue in each case, which was frozen and macerated in liquid nitrogen using a sterile mortar and pestle. After the final wash in ethanol, the extracted nucleic acid was suspended in 30 to $50 \mathrm{uL}$ of Tris-EDTA buffer solution $(10 \mathrm{mM}$ Tris- $\mathrm{HCl}, \mathrm{pH} 8.0$, and $1 \mathrm{mM}$ EDTA, $\mathrm{pH} 8.0$ ) and stored at $4^{\circ} \mathrm{C}$ until use.

Direct PCR. Total DNA was used for direct PCR amplification using CaYMV-specific primers: CaYMV-3 and CaYMV-4, which produce a 565bp fragment (Momol et al. 2004). PCR was carried out using a denaturation cycle at $95^{\circ} \mathrm{C}$ for $5 \mathrm{~min}$ and 35 cycles of amplification $\left(95^{\circ} \mathrm{C}\right.$ for $60 \mathrm{~s}, 60^{\circ} \mathrm{C}$ for $45 \mathrm{~s}, 72^{\circ} \mathrm{C}$ for $\left.60 \mathrm{~s}\right)$, with a final extension at $72^{\circ} \mathrm{C}$ for $7 \mathrm{~min}$. A mixture of $12.5 \mu \mathrm{L}$ of go taq master mix $2 \mathrm{X}$ Promega, $0.5 \mu \mathrm{L}$ of each primer, $9.5 \mu \mathrm{L}$ of water and $2 \mu \mathrm{L}$ of each DNA sample was prepared for a final volume of $25 \mu \mathrm{L}$.

RNA extraction and RT-PCR. RNA extraction and cDNA synthesis were developed at CIAT (Palmira, Valle del Cauca). The RT-PCR technique was used according to the protocol described by Carvajal et al. (2014). Between 2 and $4 \mu \mathrm{g}$ of RNA and 200 to 400ng of random primers were denatured at $65^{\circ} \mathrm{C}$ for $5 \mathrm{~min}$, followed by one minute on ice. The first cDNA chain was synthesized at $37^{\circ} \mathrm{C}$ for 1.5 hours after adding $5 \mathrm{x}$ first Strand buffer, $0.1 \mathrm{M}$ DT', $10 \mathrm{mM}$ dNTPs and $200 \mathrm{U}$ of MMLV reverse transcriptase (invitrogen) to a final volume of $15 \mu \mathrm{L}$. The quality of the cDNA was checked with a PCR of internal controls.

Once the cDNA was obtained, PCR tests were performed with specific primers for: BYMV (BYMV-F and BYMV-R) (Skelton et al. 2007), CaYSV (Canna-F1 and Canna-R2) (Monger et al. 2007), SCMV (S400-551 and S400-910) (Smith et al. 1994) and CMV and TAV (CPTALL-3 and CPTALL-5) (Choi et al. 1999), which produce fragments of 382, 695, 359 and 938 and 966bp, respectively. Primers and the positive control for SCMV were provided by Cenicaña.

In the PCR amplification tests, a mixture of $12.5 \mu \mathrm{L}$ of go taq master mix $2 X$ Promega, $0.5 \mu \mathrm{L}$ of each primer, $9.5 \mu \mathrm{L}$ of water and $2 \mu \mathrm{L}$ of each cDNA sample was prepared for a final volume of $25 \mu \mathrm{L}$. For the detection of BYMV, CaYSV and SCMV, 35 cycles were performed $\left(95^{\circ} \mathrm{C}\right.$ for $60 \mathrm{~s}, 50^{\circ} \mathrm{C}$ for $45 \mathrm{~s}$, and $72^{\circ} \mathrm{C}$ for $60 \mathrm{~s}$ ), with a final extension of $72^{\circ} \mathrm{C}$ for $7 \mathrm{~min}$. For Cucumovirus the same program was used, but using a temperature of the hybridization phase of $40^{\circ} \mathrm{C}$ for $60 \mathrm{~s}$.

Sequencing. The PCR amplification products were cleaned using the DNA precipitation method with polyethylene glycol and ethanol
(Ziv et al. 2007) and sequenced in Macrogen. The obtained sequences were compared by maximum mating and higher percentages of homology with those of reference in the GenBank, using the BLAST tool of the National Biotechnology Information Center (http://www.ncbi.nlm.nih.gov/BLAST) (Altschul et al. 1990).

Serological tests. Leaf tissue samples from asymptomatic and symptomatic achira plants were also subjected to serological tests of DAS-ELISA, with commercial antibodies (AGDIA) for the Potyvirus group, to verify the presence of viruses, following the methodology described by Clark \& Adams (1977) and recommendations from other authors such as Reichel et al. (1997).

Electron Microscopy. It was carried out at the University of Antioquia. The resin immersion method was used to process foliar tissue from very young leaves, from symptomatic achira plants. Fixation was made in 2.5\% glutaraldehyde and washed in saline buffer, postfixed in 1\% osmium tetra-oxide, washed with buffer and propylene oxide. Then it was dehydrated in an ascending gradient of ethanol from $10 \%$ to $100 \%$, to then imbibe it and include it in epoxy resin. Polymerization was carried out at $70^{\circ} \mathrm{C}$, and ultrafine cuts at $60 \mathrm{~nm}$. Subsequently, the sections were contrasted with uranyl acetate and lead citrate and were observed under a Tecnai G2 F20 transmission electron microscope.

\section{RESULTS AND DISCUSSION}

Evaluation and visual description of viral symptoms. In the department of Nariño, the achira crops have a high incidence of virus, the evaluated plants showed a wide range of foliar symptoms, which start as a yellowing, mottled mosaics, and advance to the leaf distortion; especially on the edges, chlorotic streaking, vein clearing, leaf necrosis and sometimes dwarfism, as the most outstanding (Figure 1).

Farmers call the disease as "yellow streak" because of its predominant symptom, which they correlate to a decrease in the yield of starch. Cannas economically speaking can be separated in two main groups, those used as source of food, i.e. C. edulis and those used for ornamental purposes, i.e. C. indica and related hybrids. Because ornamental and edible cannas can have different leaf color and can also have variegations in their leaves, the expression of viral symptoms on them are somewhat different depending on the variety and could lead to confusion when observing samples in the field (Rajakaruna et al. 2014). In this case, the plantations studied were planted with two different varieties (green or black), none of those are known to have variegations in their leaves, suggesting that the observed symptoms are due to physiological responses possibly caused by the presence of virus. Similar symptoms were reported in China in achira plantations affected by SCMV (Tang et al. 2016). Also, similar symptoms description due to Potyvirus infections in canna have been reported by several authors (Alexandre et al. 2017; Zakubanskiy et al. 2017; Kumari et al. 2016; Monger et al. 2007). Other virus species like a Tomato aspermy virus, Cucumovirus (TAV) (Hollings et al. 1971), Cucumber mosaic virus, Cucumovirus 


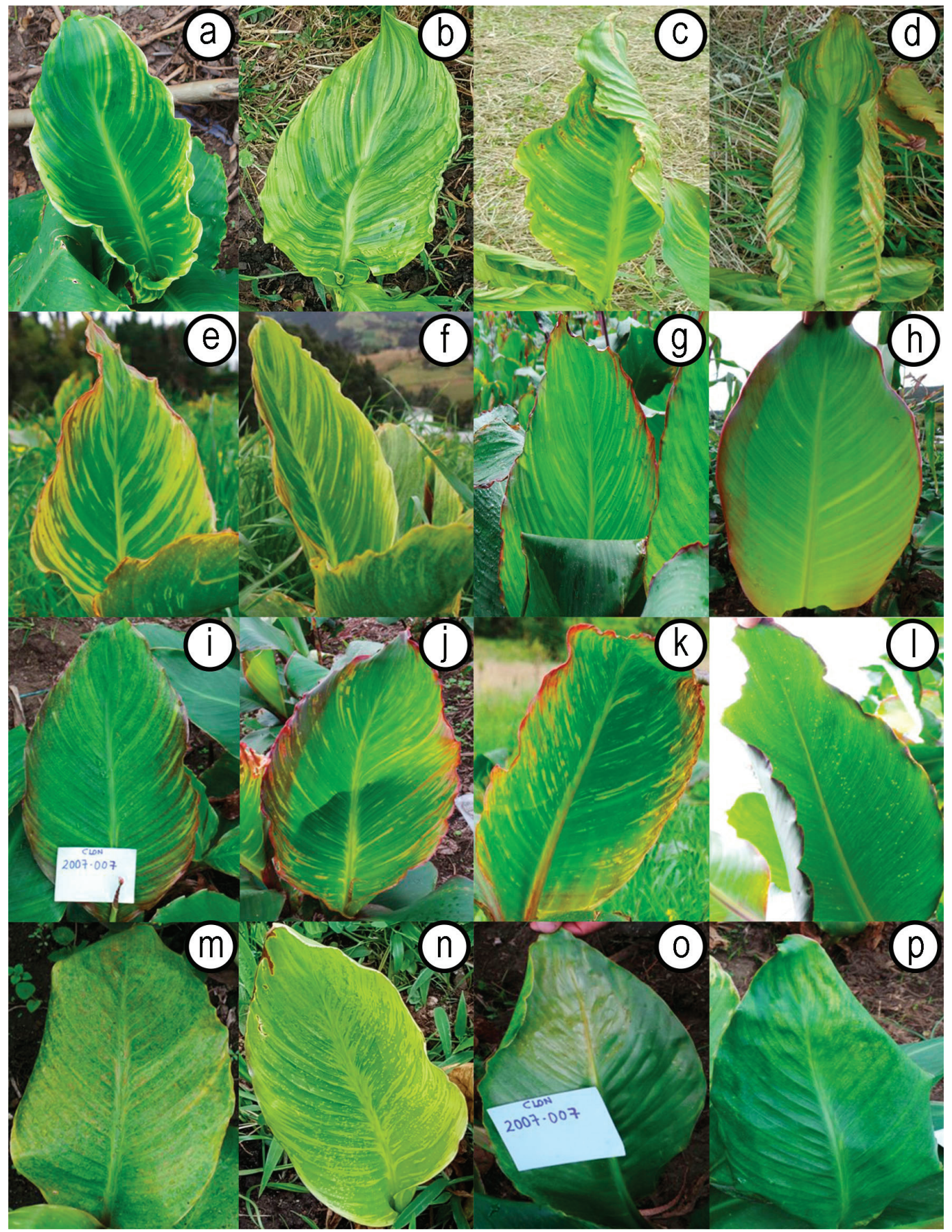

Figure1. a.-b. symptoms with veins deformation and chlorosis; c.-d. chlorosis and vein necrosis together with leaf rolling; e.-f. chlorotic bands on leaves; g.-h. symptoms of chlorotic veins and streaks; i.-k. symptoms of mosaics with different tonalities (yellow, white, green, orange and purple), set to deformation of the edge of the leaves; 1. - n. symptoms of streaks and chlorotic spots; o.-p. symptoms of chlorotic speckling on the final third of the leaf.

(CMV) (Lockhart, 1988), Canna yellow mottle virus, Badnavirus (CYMV) (Yamashita et al. 1985), because similar symptoms, but none were detected in this study.
Virus detection by molecular tests

Direct PCR. None of the collected samples amplified by direct PCR. Thus, there was no presence of Canna yellow mottle virus (CaYMV) Badnavirus (Caulimoviridae family) using specific primers. 
In exploration studies in Brazil, Alexandre et al. (2017) reported that Badnavirus amplifications were not obtained in a Canna species, with symptoms of chlorotic mosaic, but subsequent studies using RT-PCR showed the presence of a Potyvirus in the same samples.

RT-PCR. Negative results were obtained for the TAV, CMV, BYMV and CaYSV viruses, but positive results were obtained for the Sugarcane mosaic virus (SCMV) Potyvirus, in (20/30) symptomatic samples examined, corresponding to $66 \%$. One of the gels is shown in figure 2.

Molecular diagnostic tests revealed that a high proportion of plants were infected with SCMV, pointing to an association with the "yellow stripped" disease in the department of Nariño. In China,
Tang et al. (2016) similarly detected SCMV infecting Canna spp. While the similarity of symptoms of the "yellow stripped" disease might be confused with those of caused by CaYSV, (Rajakaruna et al. 2014), there is a phylogenetic relationship between these two viruses as shown by Chauhan et al. (2015), whom showed that CaYSV (Potyvirus), a virus that affects achira, belongs to the subgroup of SCMV.

Sequencing. Sanger sequencing of the sugarcane mosaic virus (SCMV) RT-PCR amplification products were performed and the sequences compared for maximum identity and coverage against the available sequences deposited at the Gene Bank of the National Center for Biotechnology Information (NCBI), using the BLAST tool of the National Biotechnology Information Center. The
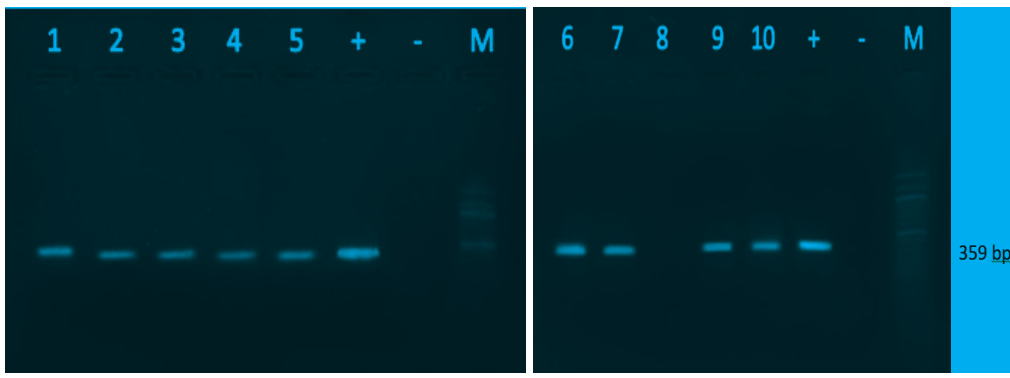

Figure 2. $1 \%$ of agarose gel, Lanes 1 to 5 and 6 to $10 \mathrm{cDNA}$ samples from achira plant tissue, M: molecular weight marker of 100 bp (Thermoscientific), +: positive control, SCMV cDNA donated by CENICANA, -: Negative control, reaction mix without cDNA.

results indicated the resemblance of the amplified sequences to the id. AF006734.1, the partial coding sequence of the sugar cane mosaic virus coat protein, isolate Brisbane, of Australian origin. The matching fragment had a length of 286bp with no gaps and a homology of $98 \%$ to the consensus sequence of the experimental samples of (Nariño) Colombia.

Serological tests. Serological tests of DAS-ELISA were performed with commercial serological kits (AGDIA) for the genus Potyvirus in which no positive results were obtained. Negative and positive control for the assay were satisfactory (data not shown). The results suggest that perhaps a low titer of viral particles precluded the assay from recognizing the pathogen and reinforce the notion that molecular assays have higher sensitivity than serological tests. Nonetheless, in the available literature about the Agdia Poty test, there is no information about the sensitivity of the assay to different strains of SCMV. The same reported (Alexandre et al. 2017), in serological studies with polyclonal antibodies to Potyvirus in Canna.

Electron Microscopy. The tissues examination under observation in transmission electron microscope did not confirm the presence of viral particles and inclusion bodies (Figure 3). This situation is not indicative of the absence of virus because its detection requires a correct selection of samples. On the other hand, the concentration of virus in plant tissues can be low, which makes it difficult to detect it for electron microscopy.

Different viruses have been reported that are infecting the Canna spp., in countries such as the United Kingdom, Belgium, Holland, France, Italy, Austria, Israel, Kenya, Iran, India, China, Thailand, Japan, the United States and Brazil (Zakubanskiy et al. 2017).

In conclusion, this is the first report of the Sugarcane Mosaic Virus, Potyvirus (SCMV) infecting achira crops (Canna edulis ker.) in Nariño (Colombia), through the use of molecular detection techniques. The epidemiological implications on the crop are serious, because its propagation is vegetative. It is necessary to initiate studies related to vectors and cleaning of planting material.

Acknowledgment: CENICAÑA and University of Antioquia, for the collaboration provided for the development of this research. Conflict of interests: The manuscript was prepared and revised by all authors, who declare the absence of any conflict which can put the validity of the presented results in risk. 


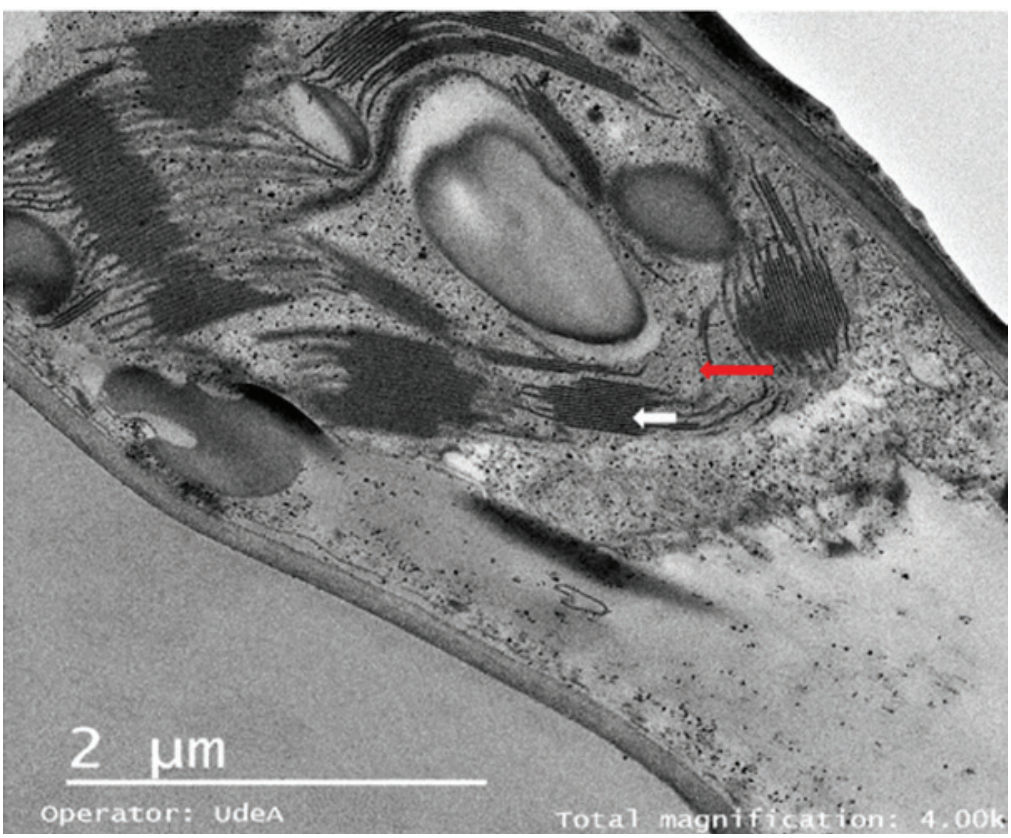

Figure 3. Electron micrographs of achira leaf tissue of the green variety. White arrow grana thylakoid and red arrow Chloroplast stroma.

\section{REFERENCES}

1. AGRONET. 2016. Estadísticas Agropecuarias. Cultivo de achira. Colombia. Disponible desde Internet en: https:// www.agronet.gov.co/ (con acceso el 01/03/2019).

2. ALTSCHUL, S.; GISH, W.; MILLER, W.; MYERS, E.; LIPMAN, D. 1990. Basic local alignment search tool. J. Molecular Biology. 215:403-410. https://doi.org/10.1016/S00222836(05)80360-2

3. ARIZA LEÓN, E.; CASTRO CELY, A.L.; GÓMEZ CAÑÓN, J.D. 2013. Factibilidad del uso del almidón de achira como agente controlador de filtrado en lodos de perforación base agua. Rev Ion. 26(1):63-71.

4. ARMITAGE, C.R.; HUNGER, R.M.; SHERWOOD, J.L.; WEEKS, D.L. 1990. Relationship between development of hard red winter-wheat and expression of resistance to wheat soilborne mosaic-virus. Plant Dis. 74:356-359. https:/ / doi.org/10.1094/PHYTO.2002.92.4.347

5. ALEXANDRE, M.A.V.; DUARTE, L.M.L.; CHAVES, A.L.R.; RAMOS, A.F.; HARAKAVA, R.; KITAJIMA, E.W. 2017. Canna paniculata as natural host of canna yellow streak virus in Brazil. Australasian Plant Dis. Notes 12:38. https://doi. org/10.1007/s13314-017-0264-3
6. CAICEDO, G.E.; ROZO, L.S.; RENGIFO, G. 2003. La achira, alternativa agroindustrial para áreas de economía campesina. Bogotá, Colombia: Corpoica. p.19.

7. CARVAJAL, M.; OLAYA, C.; LOZANO, I.; CUERVO, M.; CASTAÑO, M.; CUELLAR, W. 2014. Unraveling complex viral infections in cassava (Manihot esculenta Crantz) from Colombia. Virus Research. 186:76-86. https://doi. org/10.1016/j.virusres.2013.12.011

8. CASTAÑO, M.; ARROYAVE, J.; GÁLVEZ, G.; MORALES, F. 1995. Cucumovirus afectando plantaciones de banano y plátano en Caicedonia (Valle del Cauca). Ascolfi Informa 21(1):14-15.

9. CASTAÑO, M.; GÁlVEZ, G.E.; ARROYAVE, J.A.; VELASCO, A.C.; MORALES, F.J. 1994. Aislamiento de una cepa colombiana del virus del mosaico del banano. Fitopatología Colombiana 18:130-134.

10. CASTILLO, B.S.; YARWOOD, C.E.; GOLD, A.H. 1956. Canna mosaic virus. Plant Disease Report. 40:169-172.

11. CHAUHAN, R.P.; RAJAKARUNA, P.; VERCHOT, J. 2015. Complete genome sequence of nine isolates of canna yellow streak reveals its relationship to the sugarcane mosaic virus (SCMV) subgroup of potyviruses. Arch Virol. 160:837-844. https://doi.org/10.1007/s00705-014-2327-5 
12. CHOI, S.K.; CHOI, J.K.; PARK, W.M.; RYU, K.H. 1999. RT-PCR detection and identification of three species of cucumoviruses with a genusspecific single pair of primers. J. Virol. Methods. 83:67-73. http://dx.doi.org/10.1016/ S0166-0934(99)00106-8

13. CLARK, M.F.; ADAMS, A.N. 1977. Characteristics of the Microplate Method of Enzyme-Linked Immunosorbent Assay for the Detection of Plant Viruses. J. Gen. Virol. 34:475-483. https://doi.org/10.1099/0022-1317-34-3-475

14. CONSOLIDADO AGROPECUARIO - NARIÑO. 2015. Secretaría De Agricultura y Medio Ambiente de Nariño Corporación Colombia Internacional CCI. Cultivos Anuales. 40p.

15. Corporación colombiana de investigación agropecuaria CORPOICA. 2001. Análisis socio-económico y técnico de la mini-cadena agroindustrial de la achira. Reporte técnico. Corporación Colombiana de Investigación Agropecuaria (Corpoica) y la Organización de las Naciones Unidas para el Desarrollo Industrial (Onudi), Ministerio de Agricultura y Desarrollo Rural de Colombia, Bogotá. 97p.

16. HOLLINGS, M.; STONE, O.M. 1971. Tomato aspermy virus. CMI/AAB Descriptions of Plant Viruses. 79:1-3.

17. HUNGER, R.M.; SHERWOOD, J.L. 1985. Use of symptomatology and virus concentration for evaluating resistance to wheat soilborne mosaicvirus. Plant Dis. 69:848-850.

18. HULL, R. 2014. Plant Virology. Five edition. Academic Press. 1118p. https://doi.org/10.1016/B978-0-12-384871$0.00001-7$

19. LOCKHART, B. 1988. Occurrence of Canna yellow mottle virus in North America. Acta Hortic. 234:69-72.

20. KASEMWONG, K.; UTTAPAP, D.; PIYACHOMKWAN, K.; TAKEDA, Y. 2003. A comparative study of edible canna (Canna edulis) starch from different cultivars. Part I. Chemical composition and physicochemical properties. Carbohydr Polym. 53(3):317-324. http://dx.doi.org/10.1016/S01448617(03)00081-X

21. KUMARI, A.; RAJ, R.; KUMAR, S.; CHAUHAN, P.S.; RAJ, S.K. 2016. Coexistence of three virus genera (Badnavirus, Potyvirus and Cucumovirus) in Canna species in India. Ann Virol Res. 2(1):1008. Disponible desde Internet en: https:/ / www.jscimedcentral.com/Virology/virology-2-1008.pdf (con acceso el 01/03/2019).

22. MOINI, A.; IZADPANAH, K. 2000. New hosts for Tomato spotted wilt virus in Tehran. Iranian J. Plant Pathology. 36:104-105.
23. MOMOL, M.T.; LOCKHART, B.E.L.; DANKERS, H.; ADKINS, S. 2004. Canna yellow mottle virus detected in canna in Florida. Plant Health Progress. 5(1). https://doi. org/10.1094/PHP-2004-0809-01-HN

24. MONGER, W.A.; HARJU, V.; SKELTON, A.; SEAL, S.E.; MUMFORD, R.A. 2007. Canna yellow streak virus: a new Potyvirus associated with severe symptoms in canna. Arch Virol 152:1527-1530. https://doi.org/10.1007/s00705007-0977-2

25. PAPPU, H.; DRUFFEL, K. 2008. Canna yellow mottle virus in Canna spp. in Washington State. Plant Dis. 92:1136. https://doi.org/10.1094/PDIS-92-7-1136C.

26. PRINCE, J.; DAVIS, R.; WOLF, T.; LEE, I.; MOGEN, B.; DALLY, E.; BERTACCINI, A.; CREDI, R.; BARBA, M. 1993. Molecular detection of diverse mycoplasma like organisms (MLOs) associated with grapevine yellows and their classification with aster yellows, $\mathrm{X}$ - disease, and elm yellows MLOs. Phytopathology. 8310:1130-1137. https:/ / doi.org/10.1094/Phyto-83-1130

27. RAJAKARUNA, P.; SHAFIEKHANI, M.; KIM, T.; PAYTON, M.; CHAUHAN, R.; VERCHOT, J. 2014. Production of discernable disease phenotypes in canna by five plant viruses belonging to the genera Potyvirus, Cucumovirus, and Badnavirus. Plant Pathol. 63:821-830. https://doi. org/10.1111/ppa.12169

28. REICHEL, H. 2007. Partículas flexuosas de aspecto viral aisladas de achira (Canna edulis Ker.) afectada por clorosis en Colombia. Agronomía Colombiana 25(2):330-332.

29. REICHEL, H.; BELALCÁZAR, S.; MÚNERA, G.; ARÉVALO, E.; NARVÁEZ, J. 1996. Primer reporte del virus del rayado del banano (BSV) afectando plantaciones de plátano (Musa AAB Simmonds), caña de azúcar (Sacharum offícinorum) y achira (Canna edulis) en Colombia. Revista Corpoica. 1(1):35-39. https://doi.org/10.21930/rcta.vol1_num1_ art: 150

30. REICHEL, H.; KUMMERT, J.; LEPOIVRE, P.; BELALCÁZAR, S.; NARVÁEZ, J. 1995. Ingeniería genética para la resistencia al virus del mosaico del pepino (CMV) en especies comerciales de Musa spp. en Colombia. Revista Agrocambio. 1(2):9-16.

31. REICHEL, H.; BELALCÁZAR, S.; MUNERA, G.; ARÉVALO, E.; NARVÁEZ, J. 1997. First report of banana streak virus infecting sugarcane and arrowroot in Colombia. Plant Dis. 81:552. https://doi.org/10.1094/PDIS.1997.81.5.552B

32. ROCA, W.; MANRIQUE, I. 2005. Valorización de los recursos genéticos de raíces y tubérculos andinos para la nutrición y la salud. Agrociencia. 9(1-2):195-201. 
33. RODRÍGUEZ, G.A.; GARCÍA, H.R.; CAMACHO, J.H.; ARIAS F.L. 2003. El almidón de achira o sagú (Canna edulis Ker), manual técnico para su elaboración. Corpoica Y Programa nacional de Transferencia de tecnología Agropecuaria. Tibaitatá, Colombia, Corpoica. 33p.

34. SKELTON, A.; DALY, M.; NIXON, T.; HARJU, V.; MUMFORD, R.A. 2007. First record of Bean yellow mosaic virus infecting a member of the orchid genus Dactylorhiza. Plant Pathol. 56:344-344. https://doi. org/10.1111/j.1365-3059.2007.01530.x

35. SMITH, G.; VAN DE VELDE, R. 1994. Detection of Sugarcane Mosaic Virus and Fiji Disease Virus in Diseased Sugarcane using the Polymerase Chain Reaction. Plant Disease. 78:557-561. http://dx.doi.org/10.1094/PD-780557

36. TANAKA, N. 2004. The utilization of edible Canna plants in southeastern Asia and southern China. Econ Bot. 58(1):112-114. https://doi.org/10.1663/00130001(2004)058[0112:NOEP]2.0.CO;2

37. TANG, W.; XU, X.H.; SUN, H.W.; LI, F.; GAO, R.; YANG, S.K.; LU, X.B.; LI, X.D. 2016. First report of Sugarcane mosaic virus infecting Canna spp. in China. Plant Disease. 100:2541. https://doi.org/10.1094/PDIS-05-16-0726PDN
38. TORRES, L.J. 2004. Tecnología para el cultivo del sagú o achira (Canna edulis Ker). Ed. Produmedios (Colombia). 5-6p.

39. VERCHOT, J.; RAJAKARUNA, P. 2013. Plant viruses infecting cannas. Extension Report EPP-7327, Oklahoma State University, Stillwater.

40. YAMASHITA, S.; NATSUAKI, T.; DOI, Y.; YORA, K. 1985. Canna yellow mottle virus, a non-enveloped smallbacilliform virus in Canna sp. Ann. Phytopath. Soc. Japan. 51:642-646.

41. ZAKUBANSKIY, A.V.; MITROFANOVA, I.V.; CHIRKOV, S.N. 2017. Molecular characterization of viruses infecting canna in Russia. Plant Pathology. https://doi.org/10.1007/ s10658-017-1241-6

42. ZHANG, D.D.; BAI, G.H.; HUNGER, R.M.; BOCKUS, W.W.; YU, J.M.; CARVER, B.F.; BROWN GUEDIRA, G. 2011. Association study of resistance to soilborne wheat mosaic virus in US winter wheat. Phytopathology. 101:1322-1329. https:/ / doi.org/10.1094/PHYTO-02-11-0041

43. ZIV, A.; FUENTES, C. 2007. Improved purification and PCR amplification of DNA from elemental samples. Fems Microbiol Lett. 272(2):269-275. https://doi.org/10.1111/ j.1574-6968.2007.00764.x 